\title{
Effect of Phytase Supplementation on Body Weight, Egg Production and Quality Traits in Swarnadhara Breeders Fed Diet with Different Levels of Non-Phytate Phosphorus
}

\author{
J. N. Sreedhara ${ }^{\text {* }}$, Jayanaik ${ }^{2}$, Jagjiwan Ram², V. Malathi', \\ C. R. Gopinath ${ }^{1}$, T. M. Prabhu ${ }^{3}$ and Suguna Rao ${ }^{4}$ \\ ${ }^{1}$ Department of Poultry Science, Veterinary College, Hebbal, Bengaluru, India \\ ${ }^{2}$ Department of Animal Science, AC, Raichur, India \\ ${ }^{3}$ Department of Animal Nutrition, ${ }^{4}$ Department of Veterinary Pathology, VC, Bengaluru, India \\ *Corresponding author
}

\section{Keywords}

Non-phytate phosphorus,

Swarnadhara

breeder, Egg quality

Article Info

Accepted:

18 November 2020

Available Online:

10 December 2020

\section{A B S T R A C T}

A biological trial was conducted to study the effect of phytase supplementation on growth performance, egg production and quality traits in Swarnadhara breeders reared from 29 to 48 weeks at Department of Poultry Science, Veterinary College, Hebbal, Bengaluru. Thetrial had total 450 birds distributed to5 treatments of 90 each, treatment having three replicates, each with 30 birds. Control diet (T1) was formulated according to ICAR (2013) nutrient requirements and the groups $\mathrm{T} 2$ to $\mathrm{T} 5$ were formulated with changed non-phytate phosphorus levels so as to contain $0.12 \%$ in T2, $0.18 \%$ in T3, $0.12 \%$ NPP with $500 \mathrm{IU} / \mathrm{kg}$ phytase in T4 and $0.18 \%$ NPP with $500 \mathrm{IU} / \mathrm{kg}$ phytase in T5. Weight gain, hen day egg production and feed efficiency per dozen of eggs produced are not significantly $(\mathrm{P}>0.05)$ affected by phytase supplementation. Shell weight and shell thickness were significantly $(\mathrm{P}<0.05)$ higher in phase IV in T4. Phytase supplementation at $0.12 \%$ NPP level with phytase improved the shell thickness and shell weight in Swarnadhara breeders. NPP level of $0.12 \%$ with phytase is optimum for Swarnadhara breeders to maintain egg production and egg quality. There was no additional advantage, however, of increasing the NPP concentration above $0.12 \%$ or adding phytase to the diet containing $0.18 \%$ NPP in Swarnadhara breeders.

\section{Introduction}

The $\mathrm{P}$ requirements of broiler breeder hens have become crucial due to rise in the cost of inorganic $\mathrm{P}$ and the environmental concerns of $\mathrm{P}$ runoff. The concept of non-phytate phosphorus (NPP) requirement of chicken is gaining importance because of increasing use of vegetable protein supplements in place of animal protein supplements in poultry diets due to their cost, non-availability and contamination with pathogenic microbes. In plants, the majority of $\mathrm{P}$ is in the form of phytic acid (PA) and it salts with $\mathrm{Ca}, \mathrm{Mg}, \mathrm{Zn}$ and other divalent cations known as phytates (Pallauf and Rimbach, 1997). Phytate 
phosphorus (PP) is not available to the poultry because they do not contain sufficient amounts of intrinsic phytase required to hydrolyze the PP (Nelson, 1976; Schwarz, 1994). Therefore, poultry diets are supplemented with additional inorganic phosphorus to meet the bird's requirement. Plum stead et al., (2008) reported that NPP levels as low as $0.10 \%$ with phytase $(0.22 \%$ available $\mathrm{P}$ ) did not diminish egg production while improving water-soluble $\mathrm{P}$ retention. Phytic acid with divalent cations and amino acids not only reduces the availability of $\mathrm{P}$ but also reduces the digestibility and availability of amino acids and cations to the birds (Sebastian et al., 1998). The effect of phytase supplementation on production performance of Swarnadhara breeders fed different levels of NPP diets is yet to be investigated. Therefore, the present study was undertaken to determine the effect of phytase supplementation on production performance of Swarnadhara breeders in terms of body weight, egg production and shell quality.

\section{Materials and Methods}

\section{Birds, diet and management}

Swarnadhara breeders aged 29 weeks were randomly divided into 5 treatment groups of 90 each and housed in deep litter system. Considering 30 birds in each replicate, 3 such replicates were randomly allotted to each dietary treatment. Five isonitrogenous and isocaloric diets (Table 1) were formulated to contain $0.12,0.18$ and $0.30 \% \mathrm{NPP} / \mathrm{kg}$ diet with the two lowest NPP (0.12 and $0.18 \%$ ) diets supplemented with microbial phytase (Adventis Biolab, Bengaluru) with the activity of 500 IU per $\mathrm{kg}$ diet. Each experimental diet was offered @ $160 \mathrm{gm} / \mathrm{bird} /$ day for 20 weeks. A continuous 500 lux $16 \mathrm{~h}$ light per day was provided using incandescent bulbs. All the birds were maintained under uniform managemental conditions throughout the experimental period of 29 to 48 weeks of age, which is divided into 5 phases of four weeks duration each. All treatments and procedures were performed during the trial were approved by the Institutional Animal Ethics Committee of the university (KVAFSU, Bidar, Karnataka).

\section{Response criteria}

\section{Body weight and egg production}

Individual body weight of the birds was recorded at the beginning and at the end of the experiment. Pen wise egg production was recorded daily and \% hen day egg production (HDEP) was calculated.

\section{Egg shell quality}

Thirty eggs were randomly chosen in each treatment from the eggs laid during the last three consecutive day of each 28-day period phase to determine the shell weight, shell thickness. The cleaned eggshells were dried for $24 \mathrm{~h}$, weighed and expressed in grams. The shell thickness was measured at three different locations (middle and broad and narrow ends) using digital screw gauze with a precision of $0.01 \mathrm{~mm}$ and the mean value was taken as thickness.

\section{Statistical analysis}

The data collected on various parameters were subjected to Statistical analysis by oneway ANOVA in SPSS 20 version software. Difference between the means was tested using tukeys test at 5\% confidence level.

\section{Results and Discussion}

In the present study, Table 2 shows that supplementation of phytase enzyme resulted in insignificant variation $(\mathrm{P}>0.05)$ in body weight of Swarnadhara breeders from $29^{\text {th }}$ to 
$48^{\text {th }}$ week of age, may be due to Swarnadhara breeders taking care of phosphorus requirements at $0.12 \%$ NPP level which is optimum for them. However, neither concentration of non-phytate phosphorus nor phytase had influence on body weight gain in Swarnadhara breeders. As in the present study, Narahari and Jayaprasad (2000) found no differences in body weight gain at the level of0.18\% NPP diets with 1000 FTU $/ \mathrm{kg}$ phytase supplementation. The results obtained in present study was in agreement with the results of El-Deek et al., (2009), Hughes et al., (2008), Silversides et al., (2006) and Sukumar and Jalaudeen (2003), who observed no significant change in body weight of layers due to phytase supplementation. It may be due to genetics of the breeders which have a tendency to produce eggs rather than building up of body tissues particularly at the peak production. The effect of phytase supplementation on body weight is a secondary effect (Amin and Hamidi, 2013).

In contradictory to the results obtained in the present study, Carlos and Edwards (1998), Rao et al., (1999), Metwally (2005), Panda $e t$ al., (2005) and Mansoori and Modirsanei (2015) reported significant improvement in body weight gain with phytase supplementation.

Table.1 Percent composition of feed ingredients in the basal layer diet

\begin{tabular}{|c|c|}
\hline Ingredients & Layer Mash \\
\hline Maize & 62.50 \\
\hline Soybean meal $(46 \% \mathrm{CP})$ & 21.30 \\
\hline De-oiled rice bran & 07.40 \\
\hline Common Salt & 0.40 \\
\hline Oyster Shell grit & 7.20 \\
\hline Dicalcium Phosphate & 0.95 \\
\hline Mineral Mixture* & 0.08 \\
\hline DL-Methionine & 0.07 \\
\hline Vitamin premix $* *$ & 0.10 \\
\hline Total & 100.0 \\
\hline \multicolumn{2}{|l|}{ Nutrient Composition } \\
\hline $\mathrm{ME}(\mathrm{Kcal} / \mathrm{Kg})^{\mathrm{a}}$ & 2749 \\
\hline Crude Protein (\%) $)^{b}$ & 16.06 \\
\hline Calcium $(\%)^{b}$ & 3.05 \\
\hline Phosphorus (\%) ${ }^{b}$ & 0.574 \\
\hline Lysine $(\%)^{\mathrm{a}}$ & 0.872 \\
\hline Methionine $(\%)^{a}$ & 0.425 \\
\hline
\end{tabular}

* Mineral mixture: Each 100gm contains Magnesium oxide-1.48g., Ferrous sulphate-6g., Copper sulphate0.05g., Manganese sulphate-0.04g., Potassium iodide-0.001g., Zinc sulphate-1g. and Potassium chloride-17.09 g. ** Vitamin-mineral premix: Each 100gm contains Vitamin AD3(Vitamin A-10,00,000 IU/Kg, Vitamin D2,00,000 IU/Kg)-0.165 g, Vitamin K3-0.103 g, Vitamin E-2.4 g, Thiamine mono nitrate-0.206 g, Riboflavin$0.513 \mathrm{~g}$, Pyridoxine hydrochloride-0.309 g,Cyanocobalamine-0.00031 g, Folic acid-0.103 g,Niacin-4.124 g, CaD-Pantothenate-1.031 g, Biotin-1.5 g,Maltodextrine-89.545 g.

${ }^{\mathrm{a}}$ Calculated value, ${ }^{\mathrm{b}}$ Analysed values 
Table.2 Effect of phytase supplementation on body weight gain of Swarnadhara breeders

\begin{tabular}{|c|c|}
\hline Treatment & Body Weight Gain $(\mathbf{K g})$ \\
\hline T1 & $0.41 \pm 0.02$ \\
\hline T2 & $0.41 \pm 0.02$ \\
\hline T3 & $0.39 \pm 0.03$ \\
\hline T4 & $0.36 \pm 0.03$ \\
\hline T5 & $0.75 \pm 0.35$ \\
\hline
\end{tabular}

Table.3 Effect of phytase supplementation on hen day egg production (\%) of Swarnadhara breeders

\begin{tabular}{|c|c|c|c|c|c|}
\hline Treatment & Phase I & Phase II & Phase III & Phase IV & Phase V \\
\hline T1 & $49.86 \pm 5.11$ & $53.81 \pm 2.47$ & $45.41 \pm 4.31 \mathrm{ab}$ & $45.35 \pm 3.59 \mathrm{ab}$ & $55.15 \pm 2.14$ \\
\hline T2 & $55.09 \pm 5.16$ & $59.48 \pm 1.30$ & $55.10 \pm 2.25 \mathrm{~b}$ & $54.32 \pm 0.66 \mathrm{c}$ & $51.24 \pm 2.31$ \\
\hline T3 & $54.73 \pm 3.09$ & $55.88 \pm 4.45$ & $34.71 \pm 6.30 \mathrm{a}$ & $41.66 \pm 0.76 \mathrm{a}$ & $51.58 \pm 1.53$ \\
\hline T4 & $50.07 \pm 7.27$ & $59.75 \pm 1.68$ & $31.07 \pm 0.78 \mathrm{a}$ & $48.98 \pm 2.26 \mathrm{abc}$ & $50.84 \pm 2.96$ \\
\hline T5 & $45.81 \pm 1.51$ & $57.52 \pm 3.06$ & $38.47 \pm 5.38 \mathrm{a}$ & $51.17 \pm 3.41 \mathrm{bc}$ & $48.73 \pm 5.12$ \\
\hline
\end{tabular}

Table.4 Effect of phytase supplementation on feed efficiency per dozen of eggs produced in Swarnadhara breeders

\begin{tabular}{|c|c|c|c|c|c|}
\hline Treatment & Phase I & Phase II & Phase III & Phase IV & Phase V \\
\hline T1 & $3.68 \pm 0.36$ & $3.36 \pm 0.15$ & $4.03 \pm 0.35$ & $4.02 \pm 0.30$ & $3.28 \pm 0.12$ \\
\hline T2 & $3.33 \pm 0.34$ & $2.94 \pm 0.02$ & $3.32 \pm 0.17$ & $3.32 \pm 0.04$ & $3.53 \pm 0.15$ \\
\hline T3 & $3.30 \pm 0.20$ & $3.26 \pm 0.24$ & $5.52 \pm 0.92$ & $4.24 \pm 0.16$ & $3.53 \pm 0.09$ \\
\hline T4 & $3.52 \pm 0.38$ & $3.02 \pm 0.09$ & $5.64 \pm 0.70$ & $3.70 \pm 0.17$ & $3.57 \pm 0.12$ \\
\hline T5 & $3.94 \pm 0.12$ & $3.14 \pm 0.17$ & $4.83 \pm 0.56$ & $3.55 \pm 0.22$ & $3.83 \pm 0.46$ \\
\hline
\end{tabular}

Table.5 Effect of phytase supplementation on shell thickness (mm) in Swarnadhara breeders

\begin{tabular}{|c|c|l|l|l|l|}
\hline Treatment & Phase I & Phase II & Phase III & Phase IV & Phase V \\
\hline T1 & $0.38 \pm 0.003$ & $0.37 \pm 0.002$ & $0.35 \pm 0.002$ & $0.34 \pm 0.006 \mathrm{~b}$ & $0.38 \pm 0.001$ \\
\hline T2 & $0.38 \pm 0.002$ & $0.37 \pm 0.004$ & $0.36 \pm 0.003$ & $0.33 \pm 0.005 \mathrm{~b}$ & $0.38 \pm 0.002$ \\
\hline T3 & $0.37 \pm 0.005$ & $0.37 \pm 0.006$ & $0.36 \pm 0.004$ & $0.34 \pm 0.005 \mathrm{~b}$ & $0.37 \pm 0.001$ \\
\hline T4 & $0.39 \pm 0.002$ & $0.36 \pm 0.003$ & $0.36 \pm 0.001$ & $0.36 \pm 0.006 \mathrm{a}$ & $0.39 \pm 0.001$ \\
\hline T5 & $0.38 \pm 0.003$ & $0.36 \pm 0.003$ & $0.36 \pm 0.006$ & $0.36 \pm 0.002 \mathrm{a}$ & $0.38 \pm 0.002$ \\
\hline
\end{tabular}

Means within the column not sharing common superscript differed significantly $(\mathrm{P}>0.05)$

Table.6 Effect of phytase supplementation on shell weight (gm) in Swarnadhara breeders

\begin{tabular}{|c|c|l|l|l|l|}
\hline Treatment & Phase I & Phase II & Phase III & Phase IV & Phase V \\
\hline T1 & $5.76 \pm 0.07$ & $5.76 \pm 0.10$ & $5.58 \pm 0.09 \mathrm{~b}$ & $5.87 \pm 0.11 \mathrm{~b}$ & $5.76 \pm 0.07$ \\
\hline T2 & $5.74 \pm 0.07$ & $5.79 \pm 0.08$ & $5.69 \pm 0.07 \mathrm{ab}$ & $5.79 \pm 0.09 \mathrm{~b}$ & $5.77 \pm 0.07$ \\
\hline T3 & $5.76 \pm 0.07$ & $5.79 \pm 0.07$ & $5.83 \pm 0.09 \mathrm{ab}$ & $5.79 \pm 0.07 \mathrm{~b}$ & $5.76 \pm 0.07$ \\
\hline T4 & $5.83 \pm 0.08$ & $5.87 \pm 0.07$ & $5.97 \pm 0.10 \mathrm{a}$ & $6.41 \pm 0.12 \mathrm{a}$ & $5.83 \pm 0.08$ \\
\hline T5 & $5.82 \pm 0.07$ & $5.82 \pm 0.08$ & $5.67 \pm 0.01 \mathrm{ab}$ & $6.11 \pm 0.08 \mathrm{ab}$ & $5.82 \pm 0.07$ \\
\hline
\end{tabular}

Means within the column not sharing common superscript differed significantly $(\mathrm{P}>0.05)$ 
Phytase supplementation had no significant effect on egg production (Table 3) and feed efficiency (Table 4). However, 0.12\% NPP without phytase performed on par with control and enzyme supplemented groups indicating NPP level of $0.12 \%$ is optimum for egg production in Swarnadhara breeders. which was in agreement with Panda et al.,(2005)and Nusairat et al., (2018) who observed no significant improvement in egg production upon phytase supplementation. The insignificant variation in feed efficiency (Table 5) in this study maybe due to constant feed intake and no significant variation in egg production between dietary treatment groups in all the phases.

Egg shell weight and shell thickness: Phytase supplementation did not influence shell thickness during I, II, III and Vth phase as shown in Table 5. During IVth phase, T4 and T5hadsignificantly $(\mathrm{P}<0.05)$ higher shell thickness compared to control group and low available phosphorus groups without enzyme (T2\&T3). However, T2and T3 performed on par with control group, indicating that phytase supplementation is required in breeders to maintain optimum shell thickness, which is necessary for hatching eggs to maintain hygiene and chick quality.

The present experiment results are in agreement with the results of Nezhad and Kandi (2008), who reported that phytase addition to low NPP diets significantly improved the shell thickness at 53-64 weeks aged layers.

Shell weight (Table 6) was not influenced by phytase in all dietary treatments except in T4 during III and IV phase. Wherein; T4 had significantly $(\mathrm{P}, 0.05)$ higher shell weight than control group, indicating phytase with low phosphorus level improves shell weight. Low phosphorus (T2 \& T3) group performed on par with the control group in phase III and IV.
Which was in agreement with Jalal and Scheideler (2001) and Sohail et al., (2011) suggesting that phytase would increase calcium retention (Cabuk et al., 2004). The present study results are in contradictory to Hassanien and Elnagar (2011), who reported improvement in shell weight in all the four four-month phases. The shell weight and shell thickness were significantly higher in T4 during phase IV may be due to increased calcium retention as reported in layers (Um and Paik, 1999) caused by phytase supplementation.

It can be concluded that $0.12 \% \mathrm{NPP}$ is optimum for Swarnadhara breeders to meet their $\mathrm{P}$ requirements in terms of egg production. The NPP level beyond $0.12 \%$ was not having any additional advantage in the layer diet during the study. The addition of $500 \mathrm{IU}$ of microbial phytase $/ \mathrm{kg}$ layer diet at $0.12 \%$ NPP level would maintain shell weight and shell thickness necessary for hatching egg quality and to obtain healthy chicks during later stages of production. Phytase supplementation can reduce inorganic $P$ supplementation without affecting the production performance of Swarnadhara breeders.

\section{References}

Amin, M.R. and Hamidi, N.E., (2013). Effect of phytase supplementation on the performance of babcock-380-layer hens. Journals of Tropical Resources and Sustainable Science., 1(1): 36-41.

Cabuk, M., Bozkurt, M., Kyrkpynar, F. and Ozkul, H. 2004. Effect of phytase supplementation of diets with different levels of phosphorus on performance and egg quality of laying hens in hot climatic conditions. South Afr. J. Anim. Sci., 34: 13-17.

Carlos, A.B. and Edwards jr, H.M., (1998) The effects of $1, \quad 25$ 
dihydroxycholecalciferol and phytase on the natural phytase phosphorus utilization by laying hens. Poultry Science, 77: 850-858.

El-deek, A.A., Mona, O. and Mona, M., 2009. Effect of dietary corn gluten feed and phytase supplementation to laying hens diets. Egypt. Poult. Sci., 29: 21-38.

Hassanein, H.H.M. and Sanaa H.M. Elnagar., 2011.Comparing different levels of phytase enzyme supplementation on laying hen performance, egg quality and some blood parameters. Asian. J. Poult. Sci., 5(2):77-85.

Hughes, A.L., Dahiya, J.P., Wyatt, C.L. and Classen H.L. 2008. The efficacy of Quantum Phytase ${ }^{\mathrm{TM}}$ in a 40-week production trial using White Leghorn laying hens fed corn-soybean mealbased diets. Poult. Sci., 87: 1156-1161.

Jalal, M.A. and Scheideler, S.E., 2001. Effect of supplementation of two different sources of phytase on egg production parameters in laying hens and nutrient digestibility. Poult. Sci., 80: 1463-1471.

Mansoori, B., Modirsanei, M., 2015. Effect of dietary available phosphorus and phytase on production performance of old laying hens and tibia bone quality. Iranian Journal of Veterinary Medicine., IJVM, 9(2): 125-132.

Metwally, M.A., 2005. The effect of dietary P level with and without supplemental phytase or dried yeast on the performance of Dandarawi laying hens. Egypt. Poult. Sci., 26: 159-178.

Narahari, D. \& Jayaprasad, I.A. (2000). Effect of replacement of non-phytate phosphorus with phytate phosphorus and phytase supplementation on layers' performance. Proceedings of XXI World's Poultry Congress, Montreal, Canada.

Nelson, T. S., 1976. The hydrolysis of phytate phosphorus by chicks and laying hens. Poultry Sci. 55:2262-2264.
Nezhad, Y.E. and Kandi, J.G.G. 2008. The effects of combination of ethylene diamine tetra acetic acid (EDTA) and microbial phytase on egg quality characteristics in laying hens. J. Anim. Vet. Adv., 7: 213-216.

Nusairait, B et al., Mireille Arguelles Ramos, and John Brake., 2018. Effect of the Phytase Inclusion in Broiler Breeder Diets on Fecal and Egg Characteristics. Int.J.Poult.Sci., 17 (1):1-7.

Pallauf, J. and Rimbach, G. 1997. Nutritional significance of phytic acid and phytase. Archives of Animal Nutrition, 50: 301319.

Panda, A.K., Rama Rao, S.V., Raju M.V.L.N. and Bhanja, S.K., 2005. Effect of microbial phytase on production performance of White Leghorn layers fed on a diet low in non-phytate phosphorus. British Pout. Sci., 46(4): 464.

Plumstead, P.W., Leytem, A.B., Maguire, R.O., Spears, J.W., Kwanyuen, P. and Brake, J., 2008. Interaction of calcium and phytate in broiler diets. Effects on apparent prececal digestibility and retention of phosphorus. Poult. Sci., 87: 449-458.

Rama Rao, S.V., Reddy, R.V. and Reddy, V.R. (1999) Enhancement of phytate phosphorus availability in the diets of commercial broilers and layers. Animal Feed Science Technology, 79: 211222.

Schwarz, G., 1994. Phytase supplementation and waste management. Pages 21-44 in: Proceedings BASF Symposium Arkansas Nutrition Conference. BASF Corp., Mount Olive, NJ.

Sebastian, S., Touch Burn, S.P. and Chavez, E.R., 1998. Implications of Phytic acid and supplemented microbial phytase in poultry nutrition: a review. World's Poultry Science Journal., 54: 27-47.

Silversides, F.G., Scoot, T.A., Korvert, D.R., 
Afsharmanes, M.H. and Hruby, M., 2006. A study on the interaction of xylanase and phytase enzymes in wheat-based diets fed to commercial white and brown egg laying hens. Poult. Sci., 85: 297-305.

Sohail Hassan Khan, Muhammad Atif, Nasir Mukhtar, Abdul Rehman and Ghulam Fareed., 2011. Effects of supplementation of multi-enzyme and multi-species probiotic on production performance, egg quality, cholesterol level and immune system in laying hens. Journal of Applied Animal Research., 39(4): 386-398.

Sukumar, D. and Jalaudeen, A., 2003. Effect of supplemental phytase in diet on certain economic traits in layer chicken. Int. J. Anim. Sci., 73: 1357-1359.

Um, J.S. and Paik, I.K., 1999. Effects of microbial phytase supplementation on egg production, eggshell quality, and mineral retention of laying hens fed different levels of phosphorus. Poult. Sci., 78: 75-79.

\section{How to cite this article:}

Sreedhara, J. N., Jayanaik, Jagjiwan Ram, V. Malathi, C. R. Gopinath, T. M. Prabhu and Suguna Rao. 2020. Effect of Phytase Supplementation on Body Weight, Egg Production and Quality Traits in Swarnadhara Breeders Fed Diet with Different Levels of Non-Phytate Phosphorus. Int.J.Curr.Microbiol.App.Sci. 9(12): 2855-2861. doi: https://doi.org/10.20546/ijcmas.2020.912.340 